\title{
ANALISIS FAKTOR RESIKO YANG MEMPENGARUHI KEJADIAN ISPA PADA BAYI DAN BALITA DI PUSKESMAS BASUKI RAHMAD KOTA BENGKULU
}

\author{
Analysis Risk Factors Influence Of Incident Ari To The Infants And \\ Toddlers In The Public Health Basuki Rahmad Bengkulu City
}

\author{
Indaryani $^{1}$, Putri Melati ${ }^{2}$ \\ Program Studi Keperawatan Akademi Kesehatan Sapta Bakti Bengkulu \\ indrayani101182@gmail.com
}

\begin{abstract}
ABSTRAK
Sebuah masalah di dunia pada bayi dan balita adalah ISPA, ISPA adalah suatu penyakit infeksi yang masuk ke dalam daftar 10 penyakit terbanyak, World Health Organization (WHO) tahun 2013 mengatakandari tahun 2010-2015 dalam 10 juta kematian bayi dan balita sebagian besar disebabkan oleh Infeksi Saluran Pernapasan Akut (ISPA) (19\%), beberapa faktor resiko penyebab ISPA, yaitu pendidikan, pengetahuan, komponen rumah, ventilasi, rokok, asap, status nutrisi, ASI Eksklusif, BBLR dan status imunisasi. Tujuan penelitian ini adalah untuk mengetahui hubungan dari kejadian ISPA di Puskesmas Basuki Rahmad Kota Bengkulu Tahun 2016. Jenis penelitian yang di gunakan analitik dengan desain case control, populasi dalam penelitian ini adalah seluruh ibu yang memiliki bayi dan balita usia 9 bulan-4 tahun yang berkunjung ke Puskesmas Basuki Rahmad, dengan sampel sebanyak 53 ibu yang memiliki bayi dan balita dengan teknik pengambilan sampel secara consecutive sampling. Menggunakan data primer dan data sekunder, di olah secara univariate dan bivariate. Penelitian ini di laksanakan pada bulan Mei sampai Juni 2015 di Puskesmas Basuki Rahmad . Hasil analisis bivariat menggunaka uji statistic Chi-Square di dapatkan ada hubungan yang bermakna antara BBLR dengan kejadian ISPA $(\mathrm{p}=0,000)$, ada hubungan yang bermakna antara status imunisasi dengan kejadian ISPA $(\mathrm{p}=0,000)$, ada hubungan yang bermakna antara paparan asap rokok dengan kejadian ISPA $(\mathrm{p}=0,000)$, tidak ada hubungan yang bermakna antara ASI Eksklusif dengan kejadian ISPA $(\mathrm{p}=0,300)$. Di harapkan tenaga kesehatan khususnya Perawat dapat memberikan informasi kesehatan tentang bahaya merokok, pentingnya status imunisasi, dan manfaat ASI Eksklusif pada ibu dan keluarga yang memiliki bayi dan balita agar dapat menekan tingginya angka kejadian ISPA.
\end{abstract}

Kata kunci : BBLR, asap rokok, status imunisasi, ASI EKsklusif, ISPA

\begin{abstract}
A problem in the world for toddler or infants is Acute Respiratory Infection, it is a disease that is often reported as 10 major diseases, World Heallth Organization (WHO) on 2013 explained from 2010-2015 in 10 billion Mortality and the biggest caused by Acute Respiratori Infection (19\%), there are several risk factors associated with Acute Respiratory Infection, namely education, Knowledge, house components, vents, smoke, fumes, nutritional, exclusive breastfeeding, Low Birth Weight and immunization status. The goals this research is to know about related from Acute Respiratory Infection incident in Public Health Basuki Rahmad Bengkulu city on 2016. The kind of research was used analytic with case control design, population in this research is all mothers have infants and toddlers 9 months - 4 years old are visiting to Public Health Basuki Rahmad, samples are 53 mothers have infants and toddlers with technic of taking the samples is consecutive sampling, use to primary date and secondary date, and used univariate and bivariate analysis. This research to did on May-June on 2016 in public health Basuki Rahmad. The results of bivariate Analysis use chi-square statistical test to amounts have related between Low Birth Weight with Acute Respiratory infection $(p=0,000)$, have related between immunization status with Acute respiratory infection $(p=0,000)$, have expected related fumes smoke with Acute Respiratory Infection $(p=0,000)$, don't have expected related exclusive breastfeeding with Acute Respiratory Infection ( $p=0,300)$. In expectation medical officer especially nurses can giving healthy information about the danger of cigarette smoke, the important about immunization status, and benefit of Exclusive breastfeeding and ingredients of it to the mothers and families have toddlers can make lower of the Acute respiratory infection incidence.
\end{abstract}

Keyword: Low Birth Weight, Smoke Fumes, Immunization, exclusive breastfeeding 


\section{PENDAHULUAN}

ISPA adalah suatu penyakit infeksi yang masuk ke dalam daftar 10 penyakit terbanyak, World Health Organization (WHO) tahun 2013 mengatakan dari tahun 2010-2015 dalam 10 juta kematian bayi dan balita sebagian besar disebabkan oleh Infeksi Saluran Pernapasan Akut (ISPA) (19\%), penyakit diare (17\%), malaria (8\%) dan penyakit lainnya (10\%), hal ini terjadi di negara-negara berkembang khususnya di Indonesia. Prevalensi ISPA di Indonesia pada tahun 2013, $25 \%$ tidak jauh berbeda dengan prevalensi pada tahun 2007 sebesar 25,5\%. Prevalensi ISPA yang tertinggi terjadi pada kelompok umur 1- 4 tahun sebesar $25,8 \%$ dan $<1$ tahun sebesar $22,0 \%$ (Riskesdas, 2013).

InfeksiSaluran Pernafasan Akut (ISPA) adalah penyakit infeksi yang menyerang saluran pernafasan mulai dari hidung hingga kantong paru (alveoli) termasuk jaringannya seperti sinus/rongga di sekitar hidung, rongga telinga tengah dan pleura.ISPA di sebabkan oleh bakteri, virus dan riketsia. Faktor resiko dari penyakit ISPA adalah status imunisasi tidak lengkap, tidak di berikan ASI Eksklusif, anak terpapar dengan asap rokok, anak dengan riwayat berat badan lahir rendah (BBLR), rumah berlantai tanah dan ruangan yang tidak memiliki ventilasi, selain itu penyakit ISPA juga memiliki komplikasi yang harus segera di tangani (Padila, 2012).

Komplikasi penyakit ISPA jika tidak di lakukan intervensi yang lebih lanjut akan menimbulkan resiko lainnya seperti sinusitis paranasal, meningitis purulenta hingga kematian dan yang paling penting adalah di lakukan pencegahan untuk menghindari timbulnya penyakit ISPA sampai menimbulkan komplikasi.
Pencegahan ISPA di lakukan tindakan pemberian imunisasi lengkap, memberikan ASI Eksklusif, menghindarkan anak dari asap rokok, bagi ibu hamil dapat mengkonsumsi makanan yang sehat untuk mencegah berat badan lahir rendah pada bayi, membersihkan lantai rumah agar debu tidak terhirup dan membuat ventilasi agar udara dapat bersirkulasi. Pencegahan dengan ASI Eksklusif adalah hal penting di lakukan untuk menghindari penyakit ISPA (Maryunani, 2010).

ASI Eksklusif adalah air susu ibu yang di berikan selama 0-6 bulan tanpa makanan tambahan, di dalam ASI terkandung antibodi yang baik untuk membantu anak terhindar dari penyakit infeksi seperti penyakit ISPA, sehingga anak yang diberikan ASI Eksklusif tidak mudah terserang penyakit. Berdasarkan hasil penelitian Utomo tahun 2015 dari Universitas BSI Bandung, pengaruh pemberian ASI eksklusif dengan kejadian Infeksi Saluran Pernafasan Akut pada anak usia 6 - 23 bulan di Kabupaten Konawe menyatakan riwayat pemberian ASI tidak eksklusif berhubungan dengan prevalensi ISPA. Prevalensi ISPA 1,8 kali lebih tinggi pada anak yang diberikan ASI tidak eksklusif dibandingkan dengan anak yang diberikan ASI eksklusif (Utomo, 2015).

Berdasarkan Buku ilmu Kesehatan Anak Fakutas Kedokteran Universitas Padjajaran, bayi yang lahir dengan BBLR memiliki kerentanan terhadap ISPA, karena bayi BBLR memiliki imunitas yang rendah. Keaktifan imunitas ini di pengaruhi oleh nutrisi yang di konsumsi oleh ibunya selama hamil sehingga berpengaruh pula pada imunitas anak. Sesuai dengan hasil penelitian oleh Deri Aprianto dari Fakultas Keperawatan Universitas BSI Bandung, bayi dan balita dengan riwayat BBLR dapat beresiko 
ISPA 3 kali di banding dengan bayi dan balita yang tidak memiliki riwayat BBLR (Aprianto, 2014).

Status Imunisasi bayi juga merupakan faktor resiko penyebab ISPA, karena imunisasi pada prinsipnya memberikan imunitas kepada bayi dan balita tanpa imunisasi lengkap anak tidak memiliki imunitas sesuai yang di harapkan, sehingga anak rentan terhadap ISPA.Berdasarkan hasil penelitian Irma Oktaviani dari Fakultas Ilmu Keperawatan Stikes Aisiyah Yogyakarta, mengatakan adanya hubungan Imunisasi terhadap kejadian ISPA, dengan resiko 2 kali lipat di banding dengan anak yang mendapatkan imunisasi lengkap (Oktaviani, 2010).

Paparan asap rokok menjadi hal penting untuk di hindari agar terhindar dari ISPA, di dalam asap rokok terkandung kurang lebih 4000 elemen-elemen racun, dan setidaknya 200 diantaranya dinyatakan berbahaya bagi kesehatan, racun utama pada rokokadalah tar, nikotin dan karbonmonoksida. Tar adalahsubstansi hidrokarbon yang bersifat di paru-paru, nikotin adalah zat adiktif yang mempengaruhi syaraf dan peredaran darah sedangkan karbonmonoksida merupakan gas polusi yang bila terhirup maka akan masuk ke saluran pernafasan hingga ke alveolus sehingga gas tersebut mengendap dan menginfeksi saluran nafas. Berdasarkan hasil penelitian yang di lakukan oleh Sri Hayati dari Fakultas Kesehatan UI mengatakan anak yang terpapar asap rokok memiliki resiko 4 kali mengalami ISPA dibandingkan anak yang tidak terpapar asap rokok (Hayati, 2012).

Berdasarkan Profil Dinas Kesehatan Kota Bengkulu Tahun 2015 menunjukkan masih tingginya angka kesakitan balita karena ISPA dari tahun ke tahun. Tahun 2013 berjumlah 14.051 orang balita, tahun
2014 menjadi 12.707 orang balita, dan pada tahun 2015 angka kejadian ISPA berjumlah 9.375 orang balita (Profil Kesehatan Bengkulu, 2015). Hasil pra penelitian pada tanggal 19 Mei 2016, angka kejadian ISPA paling tinggi terdapat di Puskesmas Basuki Rahmad Kota Bengkulu yang berjumlah 194 balita dari periode bulan Januari-April, sehingga populasi yang di ambil yaitu bayi dan balita yang datang dengan keluhan ISPA dan tidak ISPA yang berjumlah 115 orang pada bulan April .

Berdasarkan uraian latar belakang, masalah di atas dapat di rumuskan pertanyaan penelitian yaitu "Apakah ada hubungan faktor resiko (BBLR, Status Imunisasi, Papar Asap Rokok, ASI Eksklusif) dengan kejadian ISPA pada bayi dan balita di Puskesmas Basuki Rahmad Selebar Kota Bengkulu. Tujuan penelitian ini untuk mengetahui hubungan faktor resiko (BBLR, Status

Imunisasi, Paparan Asap Rokok, Asi Esklusif) dengan kejadian ISPA pada balita di Puskesmas Basuki Rahmad Selebar Bengkulu.

\section{METODE PENELITIAN}

Penelitian ini dilaksanakan di wilayah kerja di Puskesmas Basuki Rahmad Selebar Kota Bengkulu. Jenis penelitian ini adalah metode penelitian Analitik dengan menggunakan desain Case Control. Populasi penelitian ini adalah semua ibu yang memiliki anak usia 9 bulan-4 tahun yang datang ke Puskesmas Basuki Rahmad Selebar Kota Bengkulu berjumlah 115. Sampel penelitian ini sebanyak 53 orang. Sampel di ambil menggunakan Consecutive Sampling. Pengumpulan data dalam penelitian ini menggunakan alat ukur Buku KIA, buku register rawat jalan dan Kuesioner. Data 
yang digunakan adalah data primer dan skunder. Tehnik analisis data dilakukan dengan uji statistik Chi Square

HASIL PENELITIAN DAN PEMBAHASAN

Tabel 1. Hubungan BBLR dengan Kejadian ISPA pada bayi dan balita di Puskesmas Basuki Rahmat Selebar Kota Bengkulu

\begin{tabular}{|c|c|c|c|c|c|c|c|c|c|}
\hline \multirow{3}{*}{ BBLR } & \multicolumn{4}{|c|}{ ISPA bayi dan balita } & \multirow{2}{*}{\multicolumn{2}{|c|}{ Total }} & \multirow{3}{*}{$\begin{array}{c}\text { CI } \\
95 \%\end{array}$} & \multirow[t]{3}{*}{ OR } & \multirow[t]{3}{*}{$p$ value } \\
\hline & \multicolumn{2}{|c|}{ ISPA } & \multicolumn{2}{|c|}{ Tidak ISPA } & & & & & \\
\hline & $\mathrm{F}$ & $\%$ & $\mathrm{~F}$ & $\%$ & $\mathrm{~F}$ & $\%$ & & & \\
\hline $\mathrm{Ya}$ & 26 & $\begin{array}{l}68, \\
4\end{array}$ & 1 & 6,6 & 27 & 50,9 & & & \\
\hline Tidak & 12 & 31,5 & 14 & 93,3 & 26 & 49,0 & $3,565-$ & 30,333 & 0,000 \\
\hline Total & 38 & 100 & 15 & 100 & 53 & 100 & 258,064 & & \\
\hline
\end{tabular}

Berdasarkan tabel 1. diketahui bahwa 38 responden terdapat lebih dari setengahnya $26(68,4 \%)$ mengalami ISPA memiliki riwayat BBLR namun terdapat kurang dari setengahnya $12(26,3 \%)$ tidak memiliki riwayat BBLR namun terdapat sebagian kecil $1(6,6 \%)$ tidak mengalami ISPA tetapi memiliki riwayat BBLR dan sebagian besar $14(93,3 \%)$ tidak memiliki riwayat BBLR. Berdasarkan uji statistik di peroleh nilai $p=0,000$ kurang dari nilai $\alpha=0,05$ berarti ada hubungan antara BBLR dengan kejadian ISPA. Sedangkan nilai $\mathrm{OR}=30,333$ artinya bayi dan balita yang memiliki riwayat BBLR beresiko 30,333 kali mengalami ISPA.

Tabel 2. Hubungan status imunisasi dengan Kejadian ISPA pada bayi dan balita di Puskesmas Basuki Rahmat Selebar Kota Bengkulu

\begin{tabular}{|c|c|c|c|c|c|c|c|c|c|}
\hline \multirow{3}{*}{ Status Imunisasi } & \multicolumn{4}{|c|}{ ISPA Bayi dan Balita } & \multirow{2}{*}{\multicolumn{2}{|c|}{ Total }} & \multirow[t]{3}{*}{ CI $95 \%$} & \multirow[t]{3}{*}{ OR } & \multirow[t]{3}{*}{$p$ value } \\
\hline & \multicolumn{2}{|c|}{ ISPA } & \multicolumn{2}{|c|}{ Tdk ISPA } & & & & & \\
\hline & $\mathrm{F}$ & $\%$ & $\mathrm{~F}$ & $\%$ & $\mathrm{~F}$ & $\%$ & & & \\
\hline Lengkap & 4 & 10,5 & 9 & 60,0 & 13 & 24,5 & & & \\
\hline Tidak lengkap & 34 & 89,5 & 6 & 40,0 & 40 & 75,4 & $2,952-$ & 12,750 & 0,000 \\
\hline Total & 38 & 100 & 15 & 100 & 53 & 100 & 55,067 & & \\
\hline
\end{tabular}

Berdasarkan tabel 2. diketahui bahwa 38 responden terdapat sebagian besar $34(89,5 \%)$ mengalami ISPA memiliki status imunisasi tidak lengkap namun terdapat sebagian kecil $4(10,5 \%)$ responden memiliki status imunisasi lengkap namun dari 15 responden terdapat lebih dari setengahnya $9(60,0 \%)$ tidak mengalami ISPA dengan imunisasi tidak lengkap dan terdapat kurang dari setengahnya $6(40,0 \%)$ dengan imunisasi tidak lengkap. Berdasarkan uji statistik di peroleh nilai $p=0,000$ kurang $\alpha=0,05$ berarti ada hubungan antara status imunisasi dengan kejadian ISPA. Sedangkan nilai $\mathrm{OR}=12,750$ artinya bayi dan balita yang memiliki status imunisasi tidak lengkap beresiko 12,750 kali mengalami ISPA. Hal ini sejalan Hidayat (2009) bahwa status imunisasi tidak lengkap dapat berupa salah satu atau lebih jenis imunisasi tidak di dapat anak, sehingga salahsatu zat imun dapat berpengaruh terhadap kejadian ISPA

Imunisasi tidak lengkap dari hasil penelitian terdapat beberapa usia anak 
yang seharusnya sudah mendapatkan imunisasi tetapi belum mendapatkan imunisasi di karenakan 4 dari orang tua bayi dan balita lupa, 3 diantaranya keluarga yang tinggal di kebun sehingga akses pelayanan kurang memadai, 3 dari bayi dan balita mengalami sakit, 3 dari orang tua mengaku tidak tahu tentang imunisasi dan sisanya tidak di ketahui alas an mengapa bayi dan balita tidak mendapatkan imunisasi lengkap. Dalam penelitian Irma Oktaviani Tahun 2010 menunjukan balita yang mempunyai riwayat imunisasi tidak lengkap sebanyak 25 balita, terdapat 19 balita mengalami pneumonia dan 6 balita mengalami ISPA bukan pneumonia. Hal ini menunjukan bahwa lebih besar resiko terkena pneumonia balita yang tidak melakukan imunisasi lengkap seperti tidak mendapatkan imunisasi DPT dan Campak (Oktaviani, 2010).

Selain itu terdapat responden yang mengalami ISPA sebagian kecil 4 (9,5\%) memiliki status imunisasi lengkap karena terpapar asap rokok, BBLR dan masih berusia 9 bulan karena pada usia ini anak belum tercemar oleh banyak faktor seperti udara di luar rumah, karena anak yang masih berumur 9 bulan belum aktif untuk bermain keluar rumah tetapi pembentukan organ tubuh masih dalam proses perkembangan sehingga mudah terinfeksi agent dari luar (Cecily, 2010).

Selain itu dari 15 responden tidak mengalami ISPA kurang dari setengahnya $6(40,0 \%)$ yang memiliki imunisasi tidak lengkap karena tidak terpapar dengan asap rokok dan tidak memiliki riwayat BBLR dan di berikan ASI ekslusif oleh ibunya karena hal inilah anak tersebut dari ASI Eksklusif, kemudian terdapat yang tidak mengalami ISPA lebih dari setengahnya 9 $(60,0 \%)$ responden memiliki status imunisasi lengkap, hal ini terjadi karena imunisasi adalah vaksin yang mengandung virus yang telah di lemahkan untuk membantu sistem kekebalan tubuh melawan penyakit sehingga anak yang mendapatkan imunisasi yang lengkap tidak mudah terserang penyakit terutama penyakit infeksi, selain itu di dukung oleh pemberian ASI Eksklusif, tidak terpapar asap rokok dan usia anak > 1-4 tahun.

Tabel 3. Hubungan paparan asap rokok dengan Kejadian ISPA pada bayi dan balita di Puskesmas Basuki Rahmat Selebar Kota Bengkulu

\begin{tabular}{|c|c|c|c|c|c|c|c|c|c|}
\hline \multirow{3}{*}{$\begin{array}{c}\text { Paparan asap } \\
\text { rokok }\end{array}$} & \multicolumn{4}{|c|}{ ISPA Bayi dan Balita } & & & \multirow[t]{3}{*}{ CI $95 \%$} & \multirow[t]{3}{*}{ OR } & \multirow[t]{3}{*}{$p$ value } \\
\hline & \multicolumn{2}{|c|}{ ISPA } & \multicolumn{2}{|c|}{ Tdk ISPA } & \multicolumn{2}{|c|}{ Total } & & & \\
\hline & $\mathrm{F}$ & $\%$ & $\mathrm{~F}$ & $\%$ & $\mathrm{~F}$ & $\%$ & & & \\
\hline Terpapar & 38 & 100 & 7 & 46,6 & 45 & 84,9 & & & \\
\hline Tidak terpapar & 0 & 0 & 8 & 53,3 & 8 & 15,1 & $1,247-$ & 2,143 & 0,000 \\
\hline Total & 38 & 100 & 15 & 100 & 53 & 1000 & 3,681 & & \\
\hline
\end{tabular}

Berdasarkan tabel 3. diketahui bahwa 38 responden seluruhnya 38 (100\%) mengalami ISPA yang terpapar asap rokok namun tidak terdapat satupun $0(0,0 \%)$ tidak terpapar asap rokok namun dari 15 responden terdapat kurang dari setengahnya $7(46,6 \%)$ tidak mengalami ISPA tetapi terpapar asap rokok dan terdapat lebih dari setengahnya $8(53,3 \%)$ tidak terpapar asap rokok. Berdasarkan uji statistik di peroleh nilai $p=0,000$ kurang dari nilai $\alpha=0,05$ berarti ada hubungan antara paparan asap rokok dengan kejadian ISPA. Sedangkan nilai $\mathrm{OR}=2,143$ artinya bayi dan balita yang terpapar asap rokok beresiko 2,143 kali mengalami ISPA. 
Hasil penelitian di tunjukkan bahwa dari 38 responden yang mengalami ISPA seluruhnya 38 (100\%) mengalami ISPA yangterpapar dengan asap rokok hal ini terjadi karena keadaan sisem saluran pernafasan anak mengalami infeksi akibat tercemar oleh asap rokok yang mengandung virus yang hidup di udara bebas, selain itu bayi dan balita yang terpapar asap rokok akibat orang tua yang merokok di dekatnya besar sekali kemungkinan beresiko ISPA di sertai pula dengan imunisasi tidak lengkap, adanya riwayat BBLR dan ASI tidak Ekslusif, organ sistem pernafasan bayi dan balita masih dalam tahap perkembangan sehingga mudah sekali terserang penyakit (Cecily, 2010).

Asap rokok dapat mengganggu kemampuan macrophage alveolar untuk membunuh bakteri, sebuah proses yang di kenal sebagai fagositosis. Selain itu, terdapat pula penelitian yang menguji selsel yang terpapar ekstrak asap rokok dengan glukokortikoid, antiinflamasi yang umum di gunakan untuk mengobati kondisi pernafasan. Hasilnya menunjukkan bahwa obat tidak memberikan jaminan pemulihan hambatan proses fagositosis alveolar yang di sebabkan asap rokok. Pada penderita ISPA yang terpapar asap rokok akan membutuhkan waktu yang lebih lama dalam penyembuhan. Asap rokok yang di hisap, baik oleh perokok aktif maupun perokok pasif akan menyebabkan fungsi ciliary terganggu, volume lender meningkat, humoral terhadap antigen di ubah, serta kuantitatif dan kualitatif perubahan dalam komponen selalu terjadi. Beberapa dalam mekanisme pertahanan tidak akan kembali normal sebelum terbebas dari paparan asap rokok. Sehingga selama penderita ISPA masih mendapatkan paparan asap rokok akan memperlama waktu yang di butuhkan untuk penyembuhannya (Marcy, 2007).

Menurut penelitian Hayati Tahun 2012 yang menghubungkan antara paparan asap rokok hasil hisapan dari anggota keluarga pada penderita ISPA menunjukkan semakin tinggi paparan asap rokok terhadap anak maka akan memperparah episode ISPA pada bayi dan balita. Terdapat tidak satupun responden 0 $(0,0 \%)$ mengalami ISPA yang tidak terpapar asap rokok karena Anak yang tidak terpapar asap rokok tetapi terserang ISPA tidak di temukan pada interprestasi di atas, tetapi hal ini kemungkinan ini terjadi karena status gizi yang kurang dan lingkungan yang kurang sehat selain itu akibat status imunisasi yang tidak lengkap, karena anak tersebut tidak mendapat imunisasi yang dapat mencegah suatu penyakit infeksi, sebagian besar bayi dan balita terserang ISPA dapat dicegah dengan imunisasi seperti difteri, pertusis, campak, maka peningkatan cakupan imunisasi akan berperan besar dalam upaya pemberantasan ISPA. Untuk mengurangi faktor yangmeningkatkan mortalitas ISPA, diupayakan imunisasi lengkap (Smeltzer, 2012).

Selain itu dari 15 respondentidak mengalami ISPA kurang dari setengahnya $7(46,7 \%)$ tidak ISPA yang terpapar asap rokok karena anak tersebut mendapatkan imunisasi yang lengkap dan tidak memiliki riwayar BBLR, imunisasi yang lengkap sangat baik karena antibodi telah tercukupi dengan baik untuk mencegah terserang terhadap penyakit, selain itu bila anak tersebut tidak mengalami BBLR berarti sistem pernafasan telah berkembang baik sehingga bisa melawan pencemaran dari lingkungan termasuk asap rokok. Riwayat BBLR menyebabkan ISPA karena balita yang mengalami BBLR lebih besar 
resikonya untuk terdiagnosa ISPA dikarenakan pada balita BBLR organorgan pernafasannya belum matang yang menyebabkan pengembangan paru kurang adekuat, otot-otot pernafasan masih lemah dan pusat pernafasan belum berkembang (Maryunani, 2010).

Pengaruh asap rokok sangat kuat dengan kejadian penyakit infeksi terutama penyakit ISPA untuk mengatasinya di butuhkan suatu sistem pertahanan yang efektif dan efisien. Ketahanan saluran pernafasan terhadap infeksi maupun partikel dan gas yang ada di udara amat tergantung pada tiga unsure alami yang selalu terdapat pada orang sehat yaitu bagaiman keutuhan epitel mukosa dan gerak mukosilia, makrofag alveoli, dan antibody.Infeksi bakteri mudah terjadi pada saluran nafas yang sel-sel epitel mukosanya telah rusak akibat infeksi yang terdahulu. Selain itu, hal-hal yang dapat menganggu keutuhan lapisan mukosa dan gerak silia adalah asap rokok dan gas $\mathrm{CO}_{2}$ (polutan utama dalam pencemaran udara), sindroma imotil, pengobatan dengan $\mathrm{O}_{2}$ konsentrasi tinggi (25\% atau lebih). Makrofag banyak terdapat di alveoli dan akan di mobilisasi ke tempat lain bila terjadi infeksi. Asap rokok dapat menurunkan kemampuan makrofag untuk membunuh bakteri (Pugud, 2008).

Selain itu terdapat lebih dari setengahnya $8(53,3 \%)$ responden yang tidak ISPA terpapar dengan asap rokok, karena telah terhindar dari polusi yang mengandung racun yang mengendap di paru-paru terdapat juga faktor lain responden tidak mengalami ISPA yaitu anak dari ibu berpendidikan tinggi, ASI Eksklusif, status imunisasi lengkap.

Tabel 4. Hubungan ASI Eksklusif dengan Kejadian ISPA pada bayi dan balita di Puskesmas Basuki Rahmat Selebar Kota Bengkulu

\begin{tabular}{|c|c|c|c|c|c|c|c|c|c|}
\hline \multirow[t]{3}{*}{ ASI Eksklusif } & \multicolumn{4}{|c|}{ ISPA Bayi dan Balita } & \multirow{2}{*}{\multicolumn{2}{|c|}{ Total }} & \multirow[t]{3}{*}{ CI 95\% } & \multirow[t]{3}{*}{ OR } & \multirow[t]{3}{*}{$p$ value } \\
\hline & \multicolumn{2}{|c|}{ ISPA } & \multicolumn{2}{|c|}{ Tdk ISPA } & & & & & \\
\hline & $\mathrm{F}$ & $\%$ & $\mathrm{~F}$ & $\%$ & $\mathrm{~F}$ & $\%$ & & & \\
\hline Eksklusif & 12 & 31,6 & 2 & 13,3 & 14 & 26,4 & & & \\
\hline Tidak Eksklusif & 26 & 68,4 & 13 & 86,7 & 39 & 73,6 & $0,065-$ & 0,333 & 0,300 \\
\hline Total & 38 & 100 & 15 & 100 & 53 & 100 & 1,716 & & \\
\hline
\end{tabular}

Berdasarkan tabel 4. diketahui bahwa 38 responden lebih dari setengahnya $26(68,4 \%)$ mengalami ISPA yang tidak mendapatkan ASI Eksklusif namun terdapat sebagian kecil $12(31,6 \%)$ responden memiliki riwayat ASI Eksklusif namun dari 15 responden terdapat sebagian kecil $2(13,3 \%)$ tidak mengalami ISPA di berikan ASI Eksklusif dan terdapat sebagian besar $13(86,7 \%)$ di berikan ASI tidak Ekssklusif. Berdasarkan uji statistik di peroleh nilai $p=0,300$ lebih dari nilai $\alpha=0,05$ berarti tidak ada hubungan antara ASI Eksklusif dengan kejadian ISPA. Sedangkan nilai $\mathrm{OR}=$ 0,333 artinya bayi dan balita yang di berikan ASI tidak Eksklusif kurang beresiko 0,333 kali mengalami ISPA. Hasil penelitian di tunjukkan bahwa dari 38 responden yang mengalami ISPA lebih dari setengahnya $26(68,4 \%)$ yang di berikan ASI tidak Eksklusif karena anak yang tidak mendapatkan ASI eksklusif tidak memiliki transport antibodi alami dari ASI untuk mencegah terjadi ISPA, kolosterum merupakan ASi pertama yang mengandung zat anti kekebalan. 
Dalam penelitian ini di jelaskan bahwa Penberian ASI mempengaruhi kejadian ISPA, kejadian ISPA di pengaruhi oleh pemberian ASI yang tidak eksklusif, didalam ASI mengandung antibodi untuk mencegah tubuh bayi dan balita mengalami penyakit infeksi, asupan ASI yang cukup dari usia anak 0-6 bulan membuat imunitas anak meningkat hingga ia tumbuh besar.

Air Susu Ibu (ASI) adalah suatu emulsi lemak dalam larutan protein, laktosa dan garam-garam anorganik yang di sekresi oleh kelenjar mamae ibu, yang berguna sebagai makanan bagi bayinya yang banyak memiliki manfaat untuk kesehatan, Bayi yang berusia di bawah 3 bulan mempunyai angka infeksi yang rendah, karena fungsi pelindung dari antibodi ke ibu. Infeksi meningkat usia 3-6 bulan, pada waktu itu antara hilangnya antibody ke ibu dan produksi antibodi itu sendiri, sisa infeksi dari virus berkelanjutan pada waktu balita dan pra sekolah pada anak-anak berumur 5 tahun (WHO, 2012).

ASI merupakan makanan alamiah yang banyak memiliki manfaat untuk bayi, praktis, ekonomis, mudah dicerna untuk memiliki komposisi, zat gizi yang ideal sesuai dengankebutuhan dan kemampuan pencernaan bayi, dapat juga melindungi infeksi gastrointestinal.ASI tidak mengandung beta-lactoglobulin yang dapat menyebabkan alergi pada bayi. ASI juga mengandung zat pelindung (antibodi) yang dapat melindungi bayi selama 5-6 bulan pertama, seperti: Immunoglobin, Lysozyme, Complemen C3 dan C4 (Maryunani, 2010).

Menurut hasil penelitian Utomo tahun 2015 menyatakan bahwa ada hubungan yang bermakna antara pemberian ASI Eksklusif dengan kejadian penyakit ISPA.Hal ini menunjukkan prevalensi kejadian ISPA lebih besar pada anak yang diberi ASI tidak eksklusif dibandingkan pada anak yang diberi ASI secara eksklusif. Terdapat kurang dari setengahnya $12(31,6 \%)$ mengalami ISPA di berikan ASI Eksklusif karena memiliki riwayat BBLR, status imunisasi tidak lengkap dan terpapar asap rokok, usia 2 tahun 6 bulan. Riwayat BBLR menyebabkan ISPA karena balita yang mengalami BBLR lebih besar resikonya untuk terdiagnosa ISPA dikarenakan pada balita BBLR organ-organ pernafasannya belum matang yang menyebabkan pengembangan paru kurang adekuat, otototot pernafasan masih lemah dan pusat pernafasan belum berkembang (Maryunani, 2010).

Kemudian anak yang masi terserang ISPA setelah di berikan ASI Eksklusif bisa saja di sebabkan oleh status imunisasi dapat menyebabkan ISPA, karena anak tersebut tidak mendapat imunisasi lengkap yang dapat mencegah penyakit infeksi, sebagian besar bayi dan balita terserang ISPA dapat dicegah dengan imunisasi seperti difteri, pertusis, campak, maka peningkatan cakupan imunisasi akan berperan besar dalam upaya pemberantasan ISPA. Untuk mengurangi faktor yangmeningkatkan mortalitas ISPA, diupayakan imunisasi lengkap (Smeltzer, 2012).

Selain itu dari 15 responden tidak mengalami ISPA sebagian besar 13 $(86,7 \%)$ tidak mengalami ISPA di berikan ASI tidak Eksklusif karena anak ini tidak terpapar asap rokok, imunisasi lengkap dan tidak mengalami BBLR, seseorang yang terhirup asap rokok yang tercemar virus dapat langsung menginfeksi saluran pernafasan karena gas CO pada rokok dapat mengendap di paru-paru, selain itu 
imunisasi yang lengkap juga sangat membantu terhindar dari penyakit infeksi, seperti imunisasi campak dan DPT dapat membantu tubuh lebih kuat melawan serang penyakit, BBLR adalah suatu faktor penyebab ISPA terbanyak dalam penelitian ini, balita yang mengalami BBLR lebih besar resikonya untuk terdiagnosa ISPA dikarenakan pada balita BBLR organ-organ pernafasannya belum matang yang menyebabkan pengembangan paru kurang adekuat, otot-otot pernafasan masih lemah dan pusat pernafasan belum berkembang (Maryunani, 2010).

Selain itu, terdapat sebagian kecil 2 $(13,3 \%)$ tidak mengallami ISPA mendapatkan ASI Eksklusif, hal ini di karenakan ASI Ekklusif mengandung antibodi yang baik untuk mencegah terjadinya penyakit infeksi termasuk penyakit ISPA. Berdasarkan hasil uji chisquaredi peroleh nilai $p=0,300$ lebih dari nilai $\alpha=0,05$ berarti tidak ada hubungan antara ASi Eksklusif dengan kejadian ISPA. Nilai $\mathrm{OR}=0,333$ artinya bayi dan balita yang memiliki status ASI tidak Eksklusif beresiko 0,333 kali mengalami ISPA.

\section{KESIMPULAN}

Berdasarkan hasil pembahasan di simpulkan bahwa BBLR, status imunisasi dan paparan asap rokok sangat berpengaruh dan beresiko terkena ISPA pada bayi dan balita, sehingga faktor resiko segera di cegah agar bisa menekan angka kejadian ISPA.

\section{DAFTAR PUSTAKA}

Aprianto, D. (2014). Jurnal Kesehatan Bayi. Bandung

Asrining, siti, heni.(2010). Perawatan Balita Resiko Tinggi. Jakarta: EGC

Brunner, Suddarth, (2010). Keperawatan Medikal Bedah. Edisi 3.Jakarta: EGC

Cecily, Linda, (2010). Keperawatan Pediatri. Jakarta: EGC.

Departemen Kesehatan RI. (2010). Profil Kesehatan Indonesia. Jakarta: Depkes RI.

Depkes RI. (2013). ASI eksklusif (Diakses Mei 2016) di unduh dari http://www.depkes.go.id/

Dinas Kesehatan. (2015). Profil Kesehatan Kota Bengkulu. Bengkulu:Dinkes Kota

Hanida. (2010). Jurnal Usia Ibu dan BBLR. Jakarta

Hartono. (2012). ISPA Gangguan Pernafasan Pada Anak. Yogyakarta: Nuha Medika

Hayati, S. (2012).Jurnal kesehatan lingkungan. Jakarta

Herry, dkk. (2007). Pedoman Diagnosa dan Terapi Ilmu Kesehatan Anak Edisi 3. Bandung: Fakutas Kedokteran Universitas Padjajaran.

Hidayat A.A, (2010). Pengantar Ilmu Keperawatan Anak. Yogyakarta:Salemba Medika

Hidayat, (2009).Buku Ajar Tumbuh Kembang anak dan Remaja.Jakarta: Sagung Seto.

Huda, Amin. (2013). Aplikasi Asuhan Keperawatan NANDA Yogyakarta: MAP.

Kasron, (2012). Buku ajar Gangguan sistem Pernafasan. Yogyakarta: Nuha Medika.

Kristanto, Andri. (2003). ASI dan Kegunaannya. Yogyakarta: Nuha Medika.

Kristanto. (2015). Jurnal Ilmiah Kesehatan Keperawatan.

Marcy Tw, (2007). Bahaya Merokok. Edisi 10. Jakarta: EGC

Mayurnani, A. (2010). Buku Ajar Gangguan Kesehatan Balita. Jakarta: Erlangga

Mutaqqin, Arif. (2009). Perawatan Gawat nafas pada balita. Jakarta: Erlangga.

Nelson, (2010). Perawatan Gangguan Saluran Pernafasan. Yogyakarta: Deep Publish

Ngastiyah, (2012).Perawatan Anak Sakit. Jakarta: EGC

Notoatmodjo, S, (2002). Metodologi Penelitian Kesehatan. Jakarta; Rineka Cipta.

Oktavia, N. (2015). Sistematika Penulisan Karya Ilmiah. Yogyakarta: Deep Publish

Oktaviani, I. (2010). Jurnal Status Imunisasi. Yogyakarta

Padila, (2012). Buku Ajar Keperawatan Medikal Bedah. Yogyakarta: Nuha Medika.

Roy, Simon, (2012). Lectures Notes Pediatrika. Jakarta: Erlangga

Smeltzer, Suzanne, dkk. (2012). Keperawatan medikal bedah. Edisi 12. Jakarta: EGC 
Utomo, (2015).Jurnal Kesehatan nutrisi bayi.

Bandung 